\title{
Chemical Profile of Malva Neglecta and Malvella Sherardiana by Lc- MS/MS, GC/MS and Their Anticholinesterase, Antimicrobial and Antioxidant Properties With Aflatoxin-Contents
}

Nesrin Hasimi, Abdulselam Ertaş, Elif Varhan Oral, Hüseyin Alkan, Mehmet Boğa, Mustafa Abdullah Yilmaz, İsmail Yener, Işıl Gazioğlu, Cumali Özaslan, Mehmet Akdeniz, Ufuk Kolak

\begin{abstract}
The purpose of the present work was to calculate the phenolic and the fatty acids profiles by LC-MS/MS and GC/MS with their antioxidant, anticholinesterase and antimicrobial activities, and aflatoxin contents of Malva neglecta and Malvella sherardiana. The phenolic contents of $M$. neglecta and $M$. sherardiana were determined by LC-MS/MS. Malic and 4-OH benzoic acids were found to be the most abundant compounds in M. neglecta and $M$. sherardiana, respectively. On the other hand, essential oils and fatty acids composition were determined by GC/MS analysis. The methanol extracts of the plants showed the highest effect in all antioxidant assays of this study. The methanol extract of
\end{abstract}

Nesrin Hasimi

Department of Nutrition and Dietetics, School of Health, Batman University, Batman

Abdulselam Ertaş

Department of Pharmacognosy, Faculty of Pharmacy, Dicle University, Diyarbakır

Elif Varhan Oral, İsmail Yener

Department of Analytical Chemistry, Faculty of Pharmacy, Dicle University, Diyarbakır

Hüseyin Alkan

Department of Biochemistry, Faculty of Pharmacy, Dicle University, Diyarbakır

Mehmet Boğa

Department of Pharmaceutical Technology, Faculty of Pharmacy, Dicle University, Diyarbakır

Mustafa Abdullah Yilmaz

Research and Application of Science and Technology Center (DÜBTAM), Dicle University, Diyarbakır

Işıl Gazioğlu

Deparment of Analytical Chemistry, Faculty of Pharmacy, Bezmialem Vakif University, Istanbul

Cumali Özaslan

Department of Planet Protection, Faculty of Agriculture, Dicle University, Diyarbakır

Mehmet Akdeniz

Department of Chemistry, Diyarbakur Chairmanship, The Council of Forensic Medicine The Ministry of Justice, Diyarbakır

Ufuk Kolak

Department of General and Analytical Chemistry, Faculty of Pharmacy, Istanbul University, Beyazt, Istanbu

Corresponding Author:

Abdulselam Ertaş

e-mail:abdulselamertas@hotmail.com,abdulselam.ertas@dicle.edu.tr

Submitted / Gönderilme: 30.12 .2016

Revised / Düzeltme: 27.01.2017

Accepted / Kabul: $\quad 30.01 .2017$
M. neglecta showed the highest activity among the petroleum ether, acetone, methanol and water extracts against acetyl- and butyryl- cholinesterase enzymes (53.68\% and 63.95\% inhibition ratio, respectively). The acetone extracts of $M$. neglacta and $M$. sherardiana exhibited moderate activity against $C$. albicans with 18 and $17 \mathrm{~mm}$ inhibion zone diameter, respectively. The results of the present study is also showed that the M. neglecta and $M$. sherardiana can also be used as a food source due to its high phenolic acid content and good antioxidant property. Also, the samples were aflatoxin free.

Keywords: Anticholinesterase; antioxidant; Malva neglecta; Malvella sherardiana; LC-MS/MS, GC-MS

\section{INTRODUCTION}

Malvaceae family includes the genera Malva L. and Malvella JAUB \& SPACH. The genus Malva is represented by 26 species in all over the World and 9 species growing in Turkey (1). $M$. neglecta Wallr. is distributed in Europae, Africa and Asia. It is called as ebegümeci, develik, gömeç, kömeç, ebegömeci and tolık by local people in Turkey. Leaves and flowers has a wide range of usage area in the treatment of constipation, sore throat, women sterility, wound, hemorrhoids, miscarriage swellings, rheumatic pain, stomachache, abdominal pain, abscess, renal diseases, ease cough, throat infection, peptic ulcer, common cold, stomachache, bronchitis, indigestion in Turkey (2-4).

In literature, there are some studies on Malva species. The anti-ulcerogenic (5), antibacterial (6), antioxidant properties and total phenolic contents of $M$. neglecta was investigated (7-8). Moreover, polyphenols and their antioxidant activity in callus-cultured M. neglecta cells under UV-B and UV-C irradiation were also reported (9). In vitro antioxidant and enzyme inhibitory properties and phenolic composition of only M. neglecta fruit were investigated (10). Macro and micro mineral content and characterization of phenolic compounds in flowers of M. neglecta and M. Sylvestris were investigated (11- 12). 
Genus Malvella is represented by 4 species in all over the world Turkey and 1 species growing in Turkey (1). M. sherardiana (L.) JAUB \& SPACH. is distributed from Europae to Caucasia and Syria. It is known as ebekömeci, ebemkömeci, ebemgömeci in Turkey. Leaves and flowers are used as food in the treatment of kidney disease and constipation (2-3). There is no report available in the literature on the chemical properties and bioliogical activities of Malvella sherardiana and Malvella species. The high content of polyprenols, which are chemotaxonomic markers, makes Malvaceae family plants exceptional among leafy plants (13).

The literature survey shows that there are no phenolic contents, essential oil and fatty acid composition or biological activity reports on $M$. sherardiana. Moreover, to our knowledge, fatty acid composition or anticholinesterase activity report on $M$. neglecta in the literature would not exist. The cooking and consumption pattern of both species which are the member of same family resemble each other (2-3), therefore we aimed to analyze both species and compare the results. Firstly, the essential oil and fatty acid compositions of $M$. neglecta and M. sherardiana were found out using GC/MS analyses, and then associated antioxidant, anticholinesterase, and antimicrobial activities, total phenolic and flavonoid contents, total aflatoxin and AFB1 levels were examined. Additionally, the phenolic and flavonoid contents of M. neglecta and M. sherardiana methanol extract were also determined using LC-MS/MS for quantitative and qualitative purposes. Also, aflatoxin contents were determined using HPLC -FLD.

\section{MATERIALS AND METHODS}

\section{Plant Material}

The whole plants in flowering stage of M. neglecta WALLR. and M. sherardiana (L.) JAUB. ET SPACH. were collected from southeastern Turkey (Diyarbakır) in July 2012 by Dr. Abdulselam Ertaş, and identified by Assist.Prof. Serpil Demirci (Çukurova University, Faculty of Pharmacy, Dept of Pharmaceutical Botany). These specimens have been stored at the Herbarium of Istanbul University (ISTE 97150 and ISTE 98928, respectively)

\section{Preparation of the Extracts And Chromatographic Conditions For Aflatoxin Analysis With HPLC-FLD}

$25 \mathrm{~g}$ aerial parts of plants were weighed and $300 \mathrm{~mL}$ of methanol (70\%) was added. Aftershaking vigorously for thirty minutes with blender (Waring, 8011.S), the extract was filtered through Whatman No. 1 filter.10 mL of the obtained filtrate was diluted with $50 \mathrm{~mL}$ of PBS and $60 \mathrm{~mL}$ of the supernatant were passed through an immunoaffinity column. After the sample had passed, the column was washed with $10 \mathrm{~mL}$ of distilled water. Finally, the column was dried with air and mycotoxins were eluted with $1.5 \mathrm{~mL}$ of methanol and added $1.5 \mathrm{~mL}$ of water into the vial. $100 \mu \mathrm{L}$ of this eluate was injected to HPLC for aflatoxin.

The instrument was used a Shimadzu LC-20 liquid chromatographic system equipped with a fluorescence detector (LC-20A) and controlled by Lab Solutions software. Separation was achieved on Cronusil-S ODS2 C18column $(25 \mathrm{~cm} \times 0.46 \mathrm{~cm} ; 5 \mu \mathrm{m})$. A post column electrochemical derivatisation was used to enhance aflatoxins responses using KOBRA -cell, $100 \mathrm{~mA}$. The injection volume was $100 \mu \mathrm{L}$ and the flow rate was $1.00 \mathrm{~mL} / \mathrm{min}$. Cromatography was performed at $40^{\circ} \mathrm{C}$ with isocratic separation a mixture of acetonitril, methanol and water $(2: 3: 6 \mathrm{v} / \mathrm{v})$ with 0.132 $\mathrm{g}$ potassium bromide, acidified with nitric acid. The wavelenghts of excitation and emissions were fixed 365 and $435 \mathrm{~nm}$. The LOD was $0.630 \mu \mathrm{g} / \mathrm{kg}$ for total aflatoxin and the recoveries were between $\%$ 83-96. Aflatoxins are toxic substances. They were always manipulated in solution, avoiding the formation of dust and aerosols. Nitrile gloves were used for all procedures.

\section{Preparation of Extracts for Biological Activities, GC/MS and LC-MS/MS}

The whole plant materials (including radix, herba, flower) used for preparation of the extracts which were dried and powdered. $100 \mathrm{~g}$ of each plant material was sequentially macerated with petroleum ether, acetone, methanol and water for 24 hour at $25^{\circ} \mathrm{C}$. To obtain the solvents were evaporated after filtration. Afterwards, dry filtrates were reconstituted in methanol at a concentration of $250 \mathrm{mg} / \mathrm{L}$ and filtered through the $0.2 \mu \mathrm{m}$ PTFE filter prior to LC-MS/ MS analysis.

\section{Esterification of Total Fatty Acids and GC/MS Conditions}

Esterification of the petroleum ether extract and GC/MS procedure described by Ertaş et al. were applied (14). Thermo Scientific Polaris Q GC-MS/MS was used.

\section{Preparation of Essential Oil and GC/MS Conditions}

Essential oils were obtained using a Clevenger apparatus from the whole parts (including radix, herba, flower) of $M$. 
neglecta and M. sherardiana, which were crumbled into small pieces and soaked in distilled water for $3 \mathrm{~h}$. The obtained essential oils were dried over anhydrous $\mathrm{Na}_{2} \mathrm{SO}_{4}$ and stored at $+4^{\circ} \mathrm{C}$ for a sufficient period of time. The essential oils were diluted using $\mathrm{CH}_{2} \mathrm{Cl}_{2}$ (1:3 volume/volume) prior to GC/FID and GC/MS analysis. GC/FID performed using Thermo Electron Trace GC FID detector and GC/MS performed using same GC and Thermo Electron DSQ quadrupole for MS. A nonpolar Phenomenex DB5 fused silica column (30 m ' $0.32 \mathrm{~mm}, 0.25 \mu \mathrm{m}$ film thickness) was used with helium at $1 \mathrm{~mL} / \mathrm{min}$ (20 psi) as a carrier gas. The GC oven temperature was kept at $60^{\circ} \mathrm{C}$ for $10 \mathrm{~min}$ and programmed to $280^{\circ} \mathrm{C}$ at a rate of $4^{\circ} \mathrm{C} / \mathrm{min}$ and then kept constant at $280^{\circ} \mathrm{C}$ for $10 \mathrm{~min}$. The split ratio was adjusted to 1:50, the injection volume was $0.1 \mu \mathrm{L}$, and $\mathrm{EI} / \mathrm{MS}$ was recorded at $70 \mathrm{eV}$ ionization energy. The mass range was $m / z$ 35-500 amu. Alkanes (C8-C24) were used as reference points in the calculation of Kovats Indices (KI) by the same conditions (15-16). Identification of the compounds was based on comparing their retention times and mass spectra with those obtained from authentic samples and/or the NIST and Wiley spectra as well as data from the published literature. GC/FID and GC/MS were replicated three times (Mean RSD \% <0.1).

\section{Determination of Total Phenolic and Flavonoid Contents}

Total phenolic and flavonoid amounts in the crude extracts expressing as pyrocatechol and quercetin equivalents were calculated according to the following equations (17-18):

Absorbance $=0.0164$ pyrocatechol $(\mu \mathrm{g})+0.0266\left(\mathrm{R}^{2}=0.9969\right)$

Absorbance $=0.1519$ quercetin $(\mu \mathrm{g})-0.1294\left(\mathrm{R}^{2}=0.9986\right)$

\section{Antioxidant Activity of the Extracts}

$\beta$-carotene-linoleic acid test system, DPPH free radical and ABTS cation radical scavenging activity and cupric reducing antioxidant capacity (CUPRAC) methods were used to determine the antioxidant activity (19-23).

\section{Anticholinesterase Activity of the Extracts}

A spectrophotometric method developed by Ellman et al. was used to indicate the acetyl- and butyryl-cholinesterase inhibitory activities (24- 25).

\section{Determination of Antimicrobial Activity}

The antimicrobial activities of the extracts against different microorganisms including yeast, Gram positive and Gram negative bacteria were assessed according to inhibition zone diameter by disc diffusion method (26). Imipenem (IPM) and Nystatin are used as positive controls for bacteria and yeast, respectively.

\section{Identification and Quantitation of Phenolic Compounds} Instruments and Chromatographic Conditions

LC-MS/MS analyses of the phenolic compounds were performed by using a Nexera model Shimadzu UHPLC coupled to a tandem MS instrument. The liquid chromatograph was equipped with LC-30AD binary pumps, DGU-20A3R degasser, CTO-10ASvp column oven and SIL$30 \mathrm{AC}$ autosampler. The chromatographic seperation was performed on a C18 reversed-phase Inertsil ODS-4 (150 mm $\times 4.6 \mathrm{~mm}, 3 \mu \mathrm{m})$ analytical column. The column temperature was fixed at $40^{\circ} \mathrm{C}$. The elution gradient consisted of mobile phase A (water, $5 \mathrm{mM}$ ammonium formate and $0.1 \%$ formic acid) and mobile phase B (methanol, $5 \mathrm{mM}$ ammonium formate and $0.1 \%$ formic acid). The gradient program with the following proportions of solvent $\mathrm{B}$ was applied $\mathrm{t}(\mathrm{min})$, \%B: $(0,40),(20,90),(23.99,90),(24,40),(29,40)$. The solvent flow rate was maintained at $0.5 \mathrm{~mL} / \mathrm{min}$ and injection volume was settled as $4 \mu \mathrm{L}$.

\section{Method Validation Parameters}

In this study, twenty-four phenolic compounds (flavonoids, flavonoid glycosides, phenolic acids, phenolic aldehyde, coumarin) and three non-phenolic organic acids that are widespread in edible plant materials were qualified and quantified in two edible plants. Rectilinear regression equations and the linearity ranges of the studied standard compounds were given in Table 1. Correlation coefficients were found to be higher than 0.99 . The limit of detection (LOD) and limit of quantitation (LOQ) of the reported analytical method were shown in Table 1. For the studied compounds, LOD ranged from 0.05 to $25.8 \mu \mathrm{g} / \mathrm{L}$ and LOQ ranged from 0.17 to 85.9 $\mu \mathrm{g} / \mathrm{L}$ (Table 1) (28). Moreover, the recoveries of the phenolic compounds ranged from $96.9 \%$ to $106.2 \%$.

\section{Statistical Analysis}

The results of the antioxidant and anticholinesterase activity assays were expressed as means $\pm \mathrm{SD}$. The results were evaluated using an unpaired $t$-test and ANOVA variance analysis with the NCSS statistical computer package. The differences were considered statistically significant at $p<0.05$. 


\section{RESULTS AND DISCUSSION}

\section{Quantitative Analysis of Phenolic and Flavonoid Compounds by LC-MS/MS}

In the quantitative analysis of phenolic compounds various studies exist in literature reporting the use of LC-MS/MS or HPLC (29-30). Therefore, an accurate quantitative method was developed on a mass spectrometer equipped with a triple quadrupole analyzer for the analyses of twenty-seven compounds (Table 1). The methanol extracts of $M$. neglecta and $M$. sherardiana were screened to quantify their phenolic composition by using a Shimadzu LCMS 8040 model liquid chromatograph combined to a triple quadrupole mass spectrometer. This accurate method allowed us to qualify and quantify 27 different compounds including several phenolic acids, flavonoids and some none-phenolic compounds. Names and molecular ions of the investigated compounds, related daughter ions found in LC-MS/MS, collision energies for the corresponding ions and the quantified results for the studied plant species are shown in Table 2.

According to the present study, it is obvious that both $M$. neglecta and $M$. sherardiana are rich in terms of phenolic acids. Their phenolic acid profile are almost paralel to each other. However, malic acid content of $M$ neglecta (13108.97 \pm $694.77 \mu \mathrm{g} / \mathrm{g})$ is considerably higher than that of $M$. sherardiana (1625.07 $\pm 86.12 \mu \mathrm{g} / \mathrm{g}$ ) (Figure 1). Both species have considerable amounts of 4-hydroxy benzoic and salicylic acids. Additionally, M. sherardiana $(1317.41 \pm 63.21 \mu \mathrm{g} / \mathrm{g})$ has higher amount of quinic acid than M. neglecta $(155.93 \pm 7.44$ $\mu \mathrm{g} / \mathrm{g}$ ). On the other hand, according to the present study, both studied species are almost poor in terms of flavonoid compounds. But we might still say that, M. sherardiana is richer than $M$. neglecta in terms of flavonoid compounds. To illustrate, $M$. sherardiana $(1429.29 \pm 70.02 \mu \mathrm{g} / \mathrm{g})$ contains good amount of hyperoside unlike M. neglecta that contains none of it. In addition, rutin $(449.00 \pm 22.45 \mu \mathrm{g} / \mathrm{g})$ and hesperidin $(591.25 \pm 28.96 \mu \mathrm{g} / \mathrm{g})$ content of $M$. sherardiana is much more than M. neglecta.

In literature, there are several sudies about $M$. neglecta but there is only one previous study related to the quantification of phenolic compounds in $M$. neglecta. In a previous study, the total phenolic, total proanthocyanidin, total 4-hydroxycinnamic acid, total flavonol and total anthocyanin contents of M. neglecta Wallr. was investigated (8). In another study a few phenolic compounds were quantified HPLCDAD and HPLC-PDA-MS (10). To add up, two studies were also conducted about determination of phenolic compounds by LC-MS/MS on Malva sylvestris (11-12). To summarize, this is the first study to screen that many of 27 compounds in $M$. neglecta and that is the only study for the phenolic compound quantification of M. sherardiana.

\section{Aflatoxin Content}

In the present investigation, aflatoxin contents were determined using HPLC with flouresence detector (Figure 2). Total aflatoxin and AFB1 were not detected in these plants, so may be they can be used in public medicine as drug. Most of the analysed food can get contaminated with aflatoxins: pre-harvest, post-harvest, during the drying process, transportation and/or in storage. Mycotoxin which is a toxic secondary metabolite of fungus can cause significant health problems. So prevention of mycotoxin contamination has become an important issue in food control to protect human and animal health.The findings of the current work exhibit that control around the world should be regularly and effectively.

\section{Fatty Acid Composition by GC-MS}

The fatty acid composition of the petroleum ether extracts were ascertained by GC/MS analysis. Eleven components were identified as it can be seen in Table 3; constituting $97.9 \%$ of the petroleum ether extract of M. neglecta. The major constituents of the fatty acid obtained from the petroleum ether extract were identified as palmitic acid (C16:0) (36.8\%), linoleic acid (C18:2 omega-6) (17.8\%) and linolenic acid (C18:3 omega-3) (13.2\%). The persentage of saturated and unsaturated faty acid is found to be $55.5 \%$ and $42.4 \%$, respectively in M.neglecta. Twelve components were ascertained, constituting $99.2 \%$ of the petroleum ether extract of M. sherardiana. The major constituents of the fatty acid obtained from the petroleum ether extract of M. sherardiana were characterized as stearic acid (C18:0) (29.9\%), palmitic acid (25.6\%), and linoleic acid (15.6\%). The persentage of saturated and unsaturated faty acid is found to be $65 \%$ and $34.2 \%$, respectively in $M$. sherardiana.

When the fatty acid compositions of $M$. neglecta and $M$. sherardiana compared, they have palmitic acid $(36.8 \%$ and $25.6 \%$, respectively), oleic acid (4.6\% and 14.5\%), linolenic acid (13.2\% and 3.2\%) and stearic acid (6.8\% and $29.9 \%)$. The persentage of saturated fatty acids is higher than unsaturated fatty acids in both species. This is the first report on the fatty acid compositions of M. neglecta and M. sherardiana.

There are some studies on fatty acid compositions of Malvaceae family in literature. The major component of 
Table 1. Analytical parameters of LC-MS/MS method

\begin{tabular}{|c|c|c|c|c|c|c|c|c|c|c|}
\hline $\begin{array}{c}\text { Analyte } \\
\text { no }\end{array}$ & Analytes & $\mathbf{R T}^{\mathrm{a}}$ & Equation & $\mathbf{R}^{2 b}$ & $\mathrm{RSD}^{\mathrm{c}}{ }^{\mathrm{C}}$ & $\begin{array}{c}\text { Linearity } \\
\text { Range }(\mathrm{mg} / \mathrm{L})\end{array}$ & $\begin{array}{l}\text { LOD/LOQ } \\
\qquad(\mu \mathrm{g} / \mathrm{L})^{\mathrm{d}}\end{array}$ & $\begin{array}{l}\text { Recover } \\
\quad(\%)\end{array}$ & & $\mathbf{U}^{e}$ \\
\hline 1 & Quinic acid & 3.36 & $f(x)=33.6626^{*} x+25132.9$ & 0.9927 & 0.0388 & $250-10000$ & $22.3 / 74.5$ & 103.3 & 4.8 & \\
\hline 2 & Malic acid & 3.60 & $f(x)=93.6102^{\star} x-5673.77$ & 0.9975 & 0.1214 & $250-10000$ & $19.2 / 64.1$ & 101.4 & 5.3 & \\
\hline 3 & tr-Aconitic acid & 4.13 & $f(x)=79.2908^{*} x-28416.2$ & 0.9933 & 0.3908 & $250-10000$ & $15.6 / 51.9$ & 102.8 & 4.9 & \\
\hline 4 & Gallic acid & 4.25 & $f(x)=358.069^{*} x+26417.5$ & 0.9901 & 0.4734 & $25-1000$ & $4.8 / 15.9$ & 102.3 & 5.1 & \\
\hline 5 & Chlorogenic acid & 5.29 & $f(x)=48.9828^{\star} x+26779.7$ & 0.9932 & 0.1882 & $250-10000$ & $7.3 / 24.3$ & 99.7 & 4.9 & \\
\hline 6 & Protocatechuic acid & 5.51 & $f(x)=36.8568^{\star} x+6197.38$ & 0.9991 & 0.5958 & $100-4000$ & $25.8 / 85.9$ & 100.2 & 5.1 & \\
\hline 7 & Tannic acid & 6.30 & $f(x)=90.2704^{*} x+30233.2$ & 0.9955 & 0.9075 & $100-4000$ & $10.2 / 34.2$ & 97.8 & 5.1 & \\
\hline 8 & tr- caffeic acid & 7.11 & $f(x)=1585.16^{*} x+83957.5$ & 0.9942 & 1.0080 & $25-1000$ & $4.4 / 14.7$ & 98.6 & 5.2 & \\
\hline 9 & Vanillin & 8.57 & $f(x)=44.5478^{\star} x-574.867$ & 0.9995 & 0.4094 & $250-10000$ & $10.1 / 33.7$ & 99.2 & 4.9 & \\
\hline 10 & p-Coumaric acid & 9.17 & $f(x)=73.5303^{*} x+27064.3$ & 0.9909 & 1.1358 & $100-4000$ & $15.2 / 50.8$ & 98.4 & 5.1 & \\
\hline 11 & Rosmarinic acid & 9.19 & $f(x)=18.0298^{*} x-1149.86$ & 0.9992 & 0.5220 & $250-10000$ & $10.4 / 34.8$ & 101.7 & 4.9 & \\
\hline 12 & Rutin & 9.67 & $f(x)=51.8835^{\star} x+3841.66$ & 0.9971 & 0.8146 & $250-10000$ & $17.0 / 56.6$ & 102.2 & 5.0 & \\
\hline 13 & Hesperidin & 9.69 & $f(x)=195.773^{\star} x+105641$ & 0.9973 & 0.1363 & $250-10000$ & $21.6 / 71.9$ & 100.2 & 4.9 & \\
\hline 14 & Hyperoside & 9.96 & $f(x)=0.978146^{*} x+827.221$ & 0.9549 & 0.2135 & $100-4000$ & $12.4 / 41.4$ & 98.5 & 4.9 & \\
\hline 15 & 4-OH Benzoic acid & 11.38 & $f(x)=635.003^{*} x+54284.6$ & 0.9925 & 1.4013 & $25-1000$ & $3.0 / 10.0$ & 106.2 & 5.2 & \\
\hline 16 & Salicylic acid & 11.39 & $f(x)=915.178^{*} x+72571.4$ & 0.9904 & 0.6619 & $25-1000$ & $4 / 13.3$ & 106.2 & 5.0 & \\
\hline 17 & Myricetin & 11.42 & $f(x)=54.2823^{*} x+5414.67$ & 0.9991 & 2.8247 & $100-4000$ & $9.9 / 32.9$ & 106.0 & 5.9 & \\
\hline 18 & Fisetin & 12.10 & $f(x)=331.870^{*} x+34409.0$ & 0.9988 & 2.4262 & $100-4000$ & $10.7 / 35.6$ & 96.9 & 5.5 & \\
\hline 19 & Coumarin & 12.18 & $f(x)=236.639^{*} x+34370.3$ & 0.9924 & 0.4203 & $100-4000$ & $9.1 / 30.4$ & 104.4 & 4.9 & \\
\hline 20 & Quercetin & 13.93 & $f(x)=206.102^{*} x+1693.14$ & 0.9995 & 4.3149 & $25-1000$ & $2.0 / 6.8$ & 98.9 & 7.1 & \\
\hline 21 & Naringenin & 14.15 & $f(x)=1100.55^{\star} x+39055.7$ & 0.9956 & 2.0200 & $25-1000$ & $2.6 / 8.8$ & 97.0 & 5.5 & \\
\hline 22 & Hesperetin & 14.80 & $f(x)=160.323^{*} x+6545.07$ & 0.9961 & 1.0164 & $25-1000$ & $3.3 / 11.0$ & 102.4 & 5.3 & \\
\hline 23 & Luteolin & 14.84 & $f(x)=111.474^{*} x+3057.10$ & 0.9992 & 3.9487 & $25-1000$ & $5.8 / 19.4$ & 105.4 & 6.9 & \\
\hline 24 & Kaempferol & 14.85 & $f(x)=20.9677^{\star} x+571.241$ & 0.9917 & 0.5885 & $25-1000$ & $2.0 / 6.6$ & 99.1 & 5.2 & \\
\hline 25 & Apigenin & 16.73 & $f(x)=543.793^{*} x+18525.6$ & 0.9954 & 0.6782 & $25-1000$ & $0.1 / 0.3$ & 98.9 & 5.3 & \\
\hline 26 & Rhamnetin & 18.41 & $f(x)=110.091^{\star} x+632.444$ & 0.9994 & 2.5678 & $25-1000$ & $0.2 / 0.7$ & 100.8 & 6.1 & \\
\hline 27 & Chrysin & 20.60 & $f(x)=698.787^{*} x+23531.7$ & 0.9965 & 1.5530 & $25-1000$ & $0.05 / 0.17$ & 102.2 & 5.3 & \\
\hline
\end{tabular}

${ }^{\mathrm{a}} \mathrm{RT}$ : Retention time, ${ }^{\mathrm{b}} \mathrm{R}^{2}$ : coefficient of determination, ${ }^{\mathrm{c}} \mathrm{RSD}$ : relative standard deviation, ${ }^{\mathrm{d}} \mathrm{LOD} / \mathrm{LOQ}(\mu \mathrm{g} / \mathrm{L})$ : Limit of deteection/Limit of quantification, ${ }^{\mathrm{e}} \mathrm{U}(\%)$ : Percent relative uncertainty at $95 \%$ confidence level $(\mathrm{k}=2)$.

the fatty acids was identified as linoleic acid (44.16-67.50\%, bettwen) for Thespesia populnea, Gossypium hirsutum (31), Malva sylvestris, M. sylvestris var. mauritiana, Althaea officinalis (32) and Hibiscus trionum (33). It is found as palmitic acid (C16:0) (36.8\%) and stearic acid (C18:0) (29.9\%) for major constitutent in M. neglecta and $M$. sherardiana against the literature survey, respectively. Even if it is not a major constituent, linoleic acid was detected as $17.8 \%$ and $15.6 \%$ in both studied species.

\section{Chemical Composition of the Essential Oils}

Essential oils were obtained using a Clevenger apparatus by hydrodistillation from the whole parts of $M$. neglecta and $M$. sherardiana. The essential oils composition of both edible plants were determined by GC/FID and GC/MS analysis (Table 4). Forty one components were determined, constituting $95.0 \%$ of the essential oil composition of $M$. neglecta. The main constituents of the essential oil were 
identified as cineole (18.8\%), hexatriacontane (7.8\%), tetratetracontane (7.8\%) and a-selinene (4.2\%) (Table 4). Eight components were determined, constituting $94.1 \%$ of the essential oil composition of $M$. sherardiana. The main constituents were 1-hexacosanol (19.1\%), a-selinene (17.5\%), 9-hexyl heptadecane (12.6\%) and 2,5-di-tert octyl-p-benzoquinone (12.1\%) (Table 4). When compared these two essential oil composition of Malvaceae family,
M. neglecta is seemed to have richer content than $M$. sherardiana. It is found that monoterpene amount of $M$. neglecta essential oil was higher than $M$. sherardiana. On the other hand, essential oil of $M$. sherardiana was rich rich in fatty acid ester and hydrocarbons. Even among the species of a genus have different chemical constitue, this different chemical composition between different genus members is not surprising. In addition to this, cineole (18.8\%) and

Table 2. Identification and quantification of phenolic compounds of methanol extracts of M. neglecta and M. sherardiana.

\begin{tabular}{|c|c|c|c|c|c|}
\hline \multirow[t]{2}{*}{ No } & \multirow[t]{2}{*}{ Compound } & \multirow[t]{2}{*}{ Parent ion $(\mathrm{m} / \mathrm{z})^{\mathrm{a}}$} & \multirow[t]{2}{*}{ MS $^{2}(\text { Collision Energy })^{\mathrm{b}}$} & \multicolumn{2}{|c|}{$\begin{array}{c}\text { Quantification } \\
(\mu \mathrm{g} \text { analyte/g extract) }\end{array}$} \\
\hline & & & & MNM & MSM \\
\hline 1 & Quinic acid & 190,95 & $85(22), 93(22)$ & $155.93 \pm 7.44$ & $1317.41 \pm 63.21$ \\
\hline 2 & Malic acid & 133,05 & $115(14), 71(17)$ & $13108.97 \pm 694.77$ & $1625.07 \pm 86.12$ \\
\hline 3 & tr-Aconitic acid & 172,85 & $85(12), 129(9)$ & $284.98 \pm 13.91$ & $207.00 \pm 10.14$ \\
\hline 4 & Gallic acid & 169,05 & $125(14), 79(25)$ & N.D. ${ }^{d}$ & N.D \\
\hline 5 & Chlorogenic acid & 353 & $191(17)$ & N.D. & N.D. \\
\hline 6 & Protocatechuic acid & 152,95 & $109(16), 108(26)$ & $282.76 \pm 14.38$ & $233.61 \pm 11.88$ \\
\hline 7 & Tannic acid & 182,95 & $124(22), 78(34)$ & N.D. & N.D. \\
\hline 8 & tr- caffeic acid & 178,95 & $135(15), 134(24), 89(31)$ & $70,38 \pm 3.65$ & N.D. \\
\hline 9 & Vanillin & 151,05 & $136(17), 92(21)$ & N.D. & $59.56 \pm$ \\
\hline 10 & p-Coumaric acid & 162,95 & $119(15), 93(31)$ & $263,32 \pm 13.41$ & $311.58 \pm 15.86$ \\
\hline 11 & Rosmarinic acid & 358,9 & $161(17), 133(42)$ & N.D. & N.D. \\
\hline 12 & Rutin & 609,1 & $300(37), 271(51), 301(38)$ & N.D. & $449.00 \pm 22.45$ \\
\hline 13 & Hesperidin & 611,1 & 303,465 & N.D. & $591.25 \pm 28.96$ \\
\hline 14 & Hyperoside & 463,1 & 300,301 & N.D. & $1429.29 \pm 70.02$ \\
\hline 15 & 4-OH Benzoic acid & 136,95 & 93,65 & $1694.92 \pm 88.09$ & $2200.57 \pm 114.42$ \\
\hline 16 & Salicylic acid & 136,95 & $93,65,75$ & $1456.04 \pm 72.80$ & $2014.27 \pm 100.70$ \\
\hline 17 & Myricetin & 317 & $179,151,137$ & N.D. & N.D. \\
\hline 18 & Fisetin & 284,95 & 135,121 & N.D. & N.D. \\
\hline 19 & Coumarin & 146,95 & $103,91,77$ & N.D & N.D. \\
\hline 20 & Quercetin & 300,9 & $179,151,121$ & N.D. & N.D. \\
\hline 21 & Naringenin & 270,95 & $151,119,107$ & N.D. & N.D. \\
\hline 22 & Hesperetin & 300,95 & $164,136,108$ & N.D. & N.D. \\
\hline 23 & Luteolin & 284,95 & $175,151,133$ & N.D. & $20.01 \pm 1.38$ \\
\hline 24 & Kaempferol & 284,95 & $217,133,151$ & N.D. & N.D. \\
\hline 25 & Apigenin & 268,95 & 151,117 & N.D. & $46.58 \pm 2.99$ \\
\hline 26 & Rhamnetin & 314,95 & $165,121,300$ & N.D. & N.D. \\
\hline 27 & Chysin & 253 & $143,119,107$ & N.D. & $3.99 \pm 0.21$ \\
\hline
\end{tabular}

aParent ion $(\mathrm{m} / \mathrm{z})$ : Molecular ions of the standard compounds (mass to charge ratio), ${ }^{\mathrm{b}} \mathrm{MS}^{2}(\mathrm{CE})$ : MRM fragments for the related molecular ions (CE refers to related collision energies of the fragment ions), ${ }^{c}$ Values in $\mu \mathrm{g} / \mathrm{g}(\mathrm{w} / \mathrm{w})$ of plant methanol extract, ${ }^{\mathrm{d}} \mathrm{N} . \mathrm{D}$ : not detected 
A

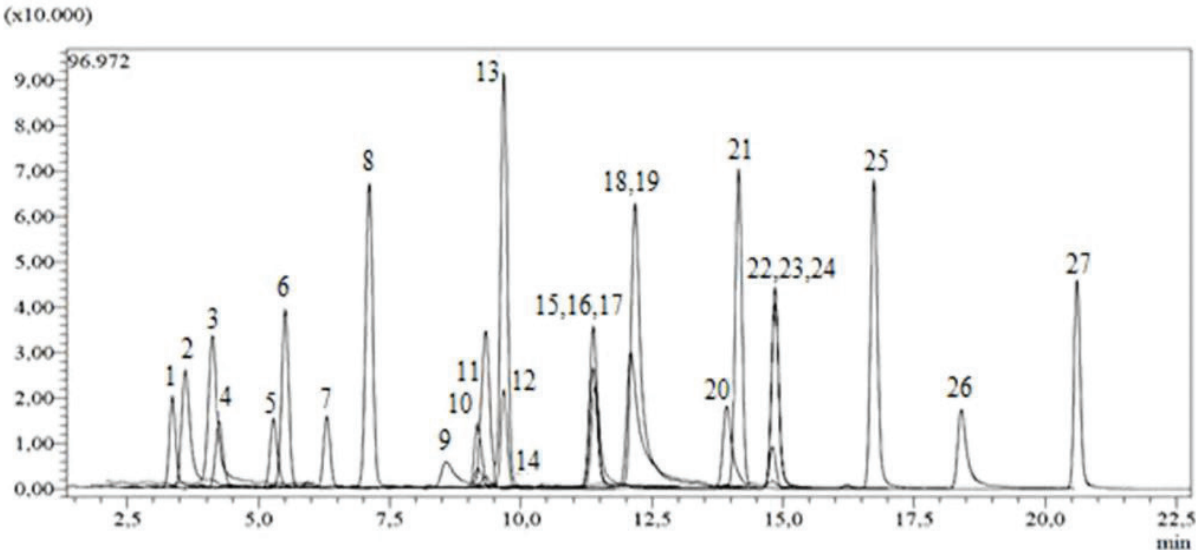

B

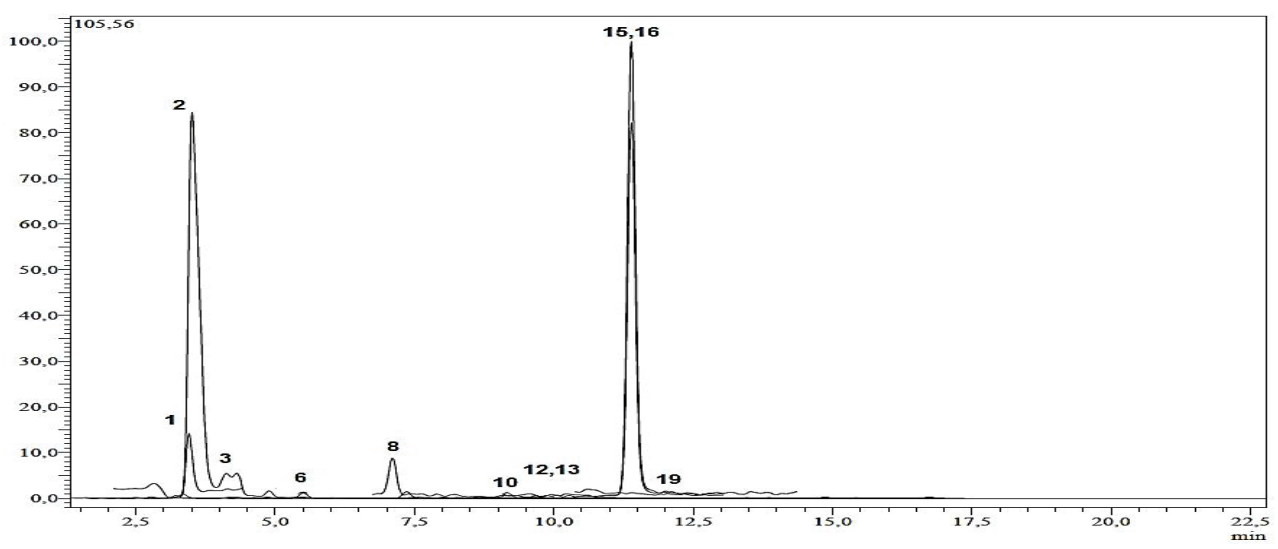

C

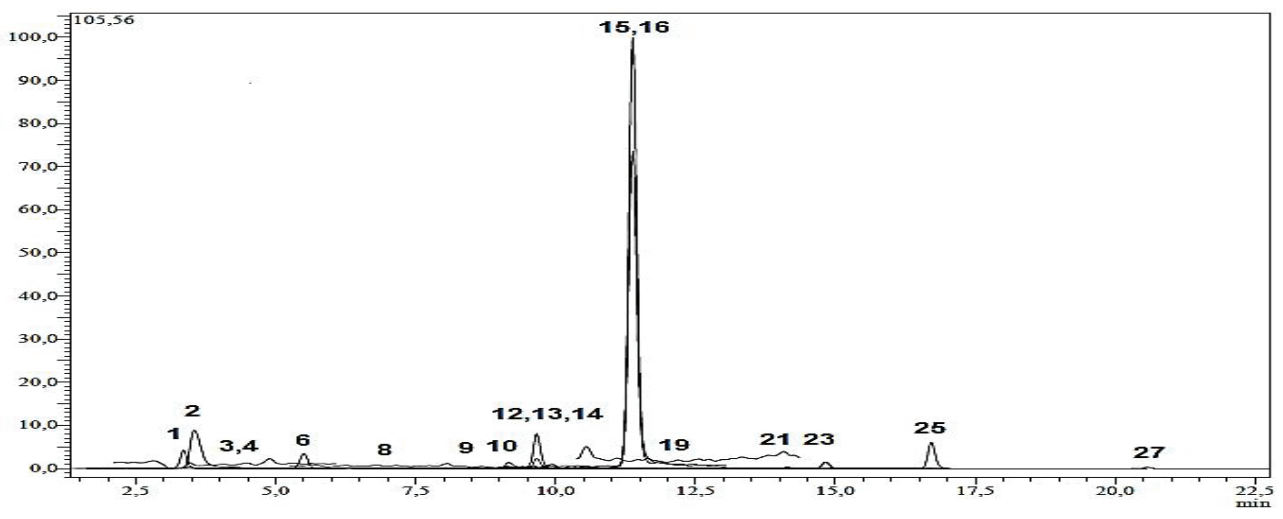

Figure 1. UHPLC-ESI-MS/MS chromatograms of A: $250 \mathrm{ppb}$ standard mix, B: M. neglacta methanol extract (MNM), C: M. sherardiana methnol extract. (MSM). 1: Quinic acid, 2: Malic acid, 3: tr-Aconitic acid, 4: Gallic acid, 5: Chlorogenic acid, 6: Protocatechuic acid, 7: Tannic acid, 8: tr- caffeic acid, 9: Vanillin, 10: p-Coumaric acid, 11: Rosmarinic acid, 12: Rutin, 13: Hesperidin, 14: Hyperoside, 15: 4-OH Benzoic acid, 16: Salicylic acid, 17: Myricetin, 18: Fisetin,19: Coumarin, 20: Quercetin, 21: Naringenin, 22: Hesperetin, 23: Luteolin, 24: Kaempferol, 25: Apigenin, 26: Rhamnetin, 27: Chrysin. 
A

$\mathrm{mV}$

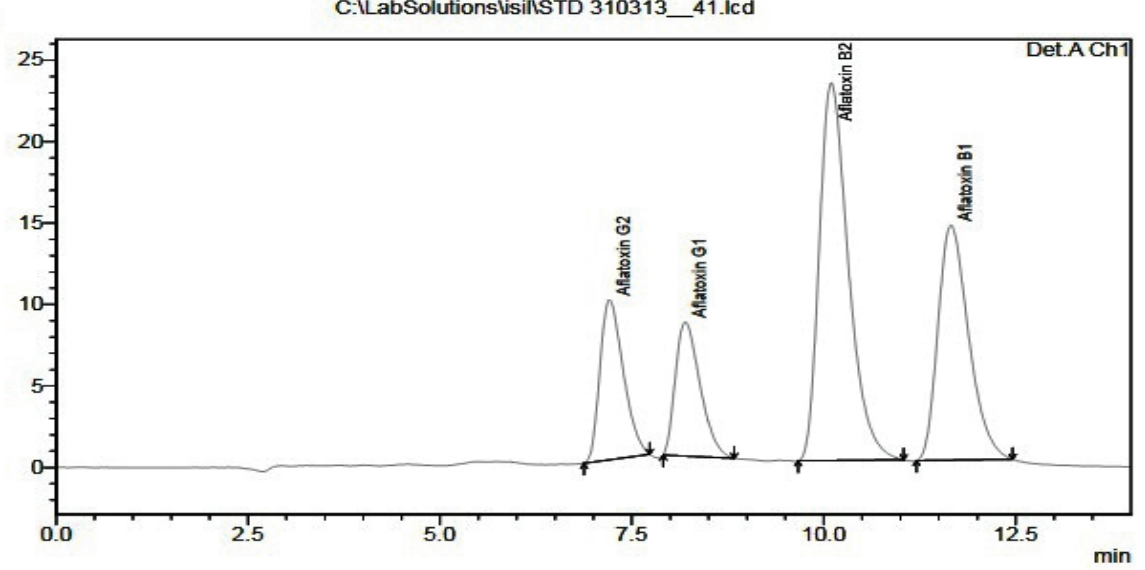

B

$\mathrm{mV}$

C:LabSolutionslisiliS4_S4_4.Icd

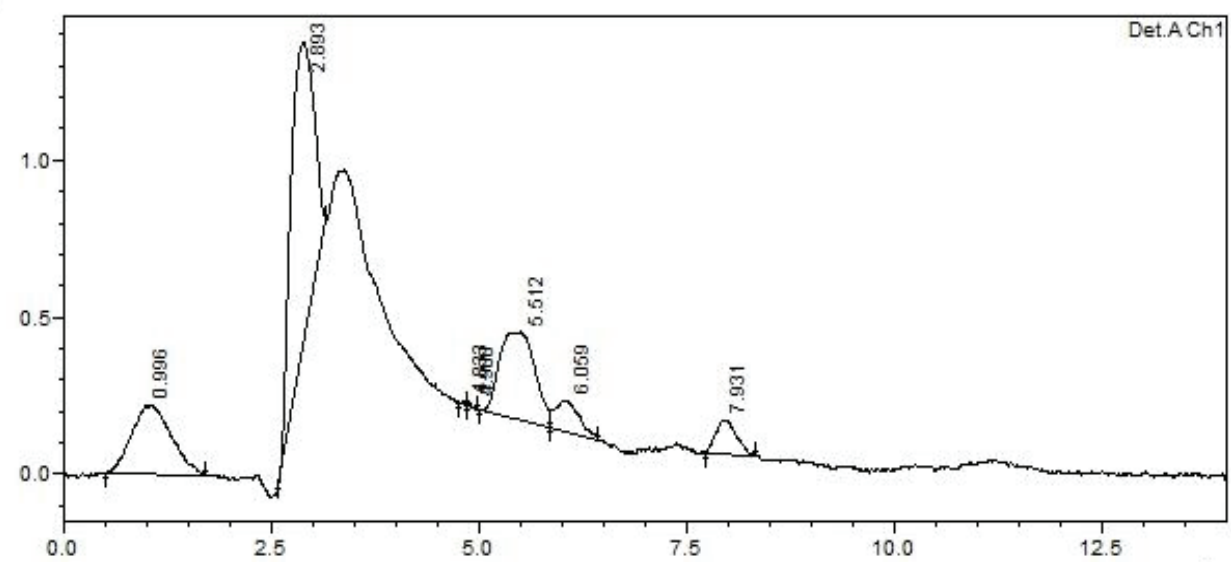

$\mathrm{C}$

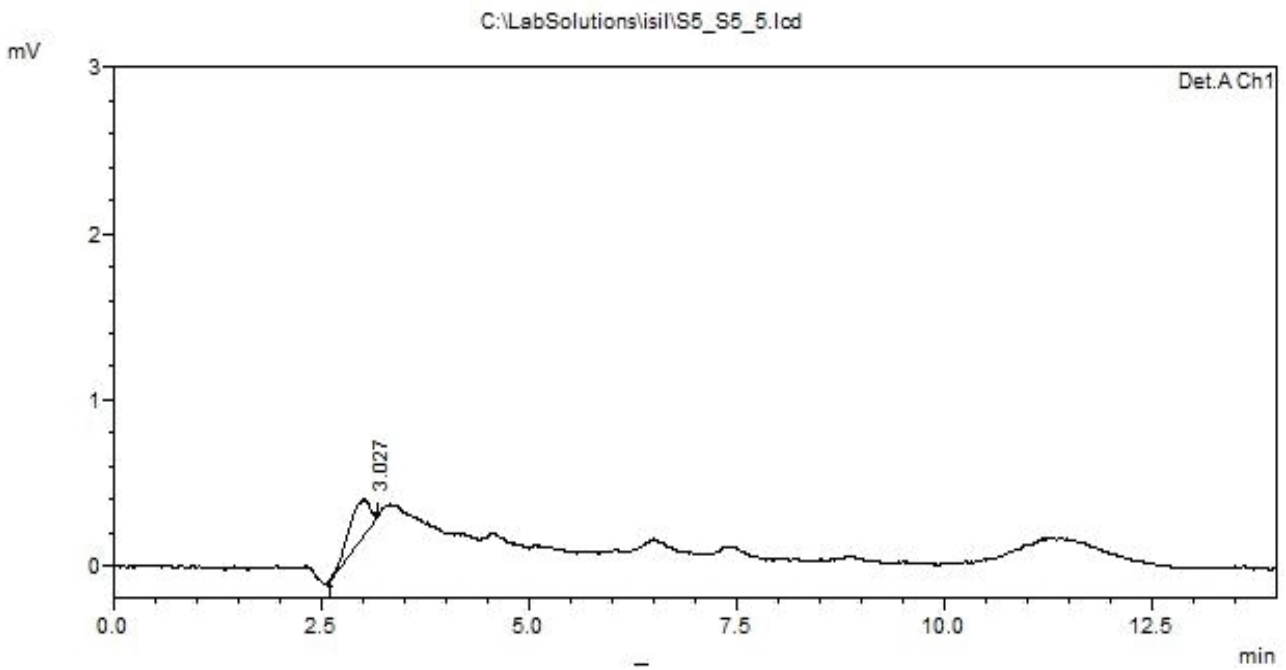

Figure 2. Aflatoxin chromatogram of A: Satandards, B: M. neglacta and C: M. sherardiana 
Table 3. GC-MS Analysis of the petroleum ether of M. neglecta and M. sherardiana

\begin{tabular}{|c|c|c|c|}
\hline $\operatorname{Rt}(\min )^{a}$ & Constituents $^{\mathrm{b}}$ & \%Composition MN & \%Composition MS \\
\hline 9.69 & Octanedioic acid & - & 0.3 \\
\hline 12.00 & Lauric acid & - & 0.9 \\
\hline 14.39 & 10-Undecenoic acid & 1.6 & - \\
\hline 18.60 & Myristic acid & 7.8 & 2.9 \\
\hline 25.27 & Palmitic acid & 36.8 & 25.6 \\
\hline 29.75 & Phytol & 2.9 & 0.9 \\
\hline 30.64 & Linoleic acid & 17.8 & 15.6 \\
\hline 30.77 & Oleic acid & 4.6 & 14.5 \\
\hline 30.86 & Linolenic acid & 13.2 & 3.2 \\
\hline 31.54 & Stearic acid & 6.8 & 29.9 \\
\hline 37.38 & Arachidic acid & 2.3 & 3.5 \\
\hline 38.19 & 6-Hexadecenoic acid & 2.3 & - \\
\hline 39.36 & Docosane & - & 0.7 \\
\hline \multirow[t]{4}{*}{43.82} & Behenic acid & 1.8 & 1.2 \\
\hline & Saturated fatty acids & 55.5 & 65 \\
\hline & Unsaturated fatty acids & 42.4 & 34.2 \\
\hline & Total & 97.9 & 99.2 \\
\hline
\end{tabular}

${ }^{\mathrm{a}}$ Retention time (as minutes), ${ }^{\mathrm{b}}$ A nonpolar Phenomenex DB-5 fused silica colum.

numerous constituents were determined in Malvaceae family for the first time.

\section{Antioxidant Activity and Total Phenolic and Flavonoid Content}

The antioxidant activity of the petroleum ether (MNP and MSP, respectively), acetone (MNA and MSA), methanol (MNM and MSM) and water (MNW and MSW) extracts prepared from the whole plant of $M$. neglecta and $M$. sherardiana were studied by using $\beta$-carotene bleaching, DPPH free radical scavenging, cupric reducing antioxidant capacity and ABTS cation radical decolorisation assays. Also,the extracts were analyzed for total phenolic and flavonoid contents. The phenolic and flavonoid components of the MSM extract were found to be the richest among all (86.59 $\mu \mathrm{g}$ PEs/mg extract and $16.11 \mu \mathrm{g}$ QEs/mg extract).
The phenolic components are seen as higher than flavonoid components. Table 5 includes the results of total phenolic and flavonoid contents, antioxidant and anticholinesterase activities of M. neglecta and M. sherardiana extracts.

The current study is the first research about total phenolic and flavonoid content of $M$. sherardiana in literature; however there is two study about M. neglecta. In the study of Dalar et al. (8), it is found that the phenolic content of M. neglecta's different parts (root, stem, leaf, flower, fruit and whole plant) was between 3.4-17.4 $\mathrm{mg} \mathrm{GAE} / \mathrm{g}$ DW; and the total flavonoid content was between 0.97-7.21 mg RE/g DW. The report of Türker and Dalar, fruit of M. neglecta $12.8 \mathrm{mg} \mathrm{GAE} / \mathrm{g}$ DW (10) and in the other study which was belong to Guder and Korkmaz, the total phenolic content of leaf and flower parts of $M$. neglecta was determined as $106.1-136.1 \mu \mathrm{g} / \mathrm{mg}$ cat.; and the total flavonid content is calculated as $22.9-46.7 \mu \mathrm{g} /$ 
Table 4. Chemical composition of the essential oil from M. neglecta (MN) and M. Sherardiana (MS)

\begin{tabular}{|c|c|c|c|}
\hline $\mathrm{RI}^{\mathrm{a}}$ & Constituents $^{\mathrm{b}}$ & $\begin{array}{c}\text { \% Composition } \\
\text { MN }\end{array}$ & $\begin{array}{c}\text { \% Composition } \\
\text { MS }\end{array}$ \\
\hline 800 & Octane & 1.7 & - \\
\hline 865 & Isononane & 1.3 & - \\
\hline 939 & a-Pinene & 1.6 & - \\
\hline 954 & Camphene & 1.1 & - \\
\hline 979 & $\beta$-Pinene & 2.9 & - \\
\hline 991 & $\beta$-Myrcene & 0.8 & - \\
\hline 1029 & Limonene & 1.0 & - \\
\hline 1031 & Cineole & 18.8 & - \\
\hline 1063 & 2-methyl decane & 0.8 & - \\
\hline 1146 & Camphor & 1.4 & - \\
\hline 1249 & 1,3-Di-tert butyl benzene & 2.4 & - \\
\hline 1276 & Carvone oxide & 0.8 & - \\
\hline 1285 & Anethole & 2.2 & - \\
\hline 1484 & Valencene & 1.7 & - \\
\hline 1498 & a-Selinene & 4.2 & 17.5 \\
\hline 1505 & $\beta$-Himachalene & 1.2 & - \\
\hline 1528 & a-Muurolene & 0.9 & - \\
\hline 1677 & Cadalene & 1.1 & - \\
\hline 1746 & 2-Methyl heptadecane & 1.6 & - \\
\hline 1800 & Octadecane & 1.6 & - \\
\hline 1890 & 2-Methyl-1-hexadecanol & 2.3 & - \\
\hline 1986 & Hexadecanoic acid & 0.9 & - \\
\hline 2109 & Heneicosane & 1.8 & - \\
\hline 2156 & 1-Nonadecanol & 1.8 & - \\
\hline 2171 & Butyl phthalate & 1.1 & 8.5 \\
\hline 2172 & 2-Eicosanol & 1.8 & - \\
\hline 2185 & Z-8-octadecen-1-ol acetate & 1.4 & 8.1 \\
\hline 2200 & Docosane & 1.3 & - \\
\hline 2243 & 9-Hexyl heptadecane & 0.7 & 12.6 \\
\hline 2259 & 2,5-Di-tert octyl-p-benzoquinone & 4.0 & 12.1 \\
\hline 2366 & Arachidic acid & 1.3 & 8.3 \\
\hline 2407 & Tetracosane & 2.3 & 7.9 \\
\hline 2413 & 3-Ethyl-5-(2-ethylbutyl)octadecane & 1.5 & - \\
\hline 2700 & Heptacosane & 0.8 & - \\
\hline 2852 & 1-Hexacosanol & 2.8 & 19.1 \\
\hline 2896 & Choleic acid & 0.9 & - \\
\hline 2900 & Nonacosane & 1.3 & - \\
\hline 3094 & Ethyl iso-allocholate & 0.8 & - \\
\hline 3508 & 17-Pentatriacontene & 1.5 & - \\
\hline 3600 & Hexatriacontane & 7.8 & - \\
\hline \multirow[t]{2}{*}{4400} & Tetratetracontane & 7.8 & - \\
\hline & Total & 95.0 & 94.1 \\
\hline
\end{tabular}

${ }^{\text {a }}$ RI Retention indices (DB-5 column), ${ }^{\mathrm{b}}$ A nonpolar Phenomenex DB- 5 fused silica column 
mg cat, respectively (7). In our study; methanol extract of $M$. neglecta and water extract of $M$. sherardiana were fond to be rich in phenolic content with 68.29 and $86.59 \mu \mathrm{g}$ PEs/mg extract, respectively.

As indicated in Table 5, the MNA, MNM and MSM extracts showed good lipid peroxidation activity $\left(\mathrm{IC}_{50}: 45.92,23.42\right.$ and $29.62 \mu \mathrm{g} / \mathrm{mL}$, respectively) in $\beta$-carotene bleaching method. The other tested extracts indicated weak or no lipid peroxidation activity in $\beta$-carotene bleaching method. In literature there exists a study about this activity of $M$. neglecta; however, the present study is a first report for M. sherardiana. Guder and Korkmaz reported that the hydroalcoholic extracts of flower and leaf of $M$. neglecta demonstrated antioxidant activities with $77.3 \%$ and $74.1 \%$ inhibition in lipid peroxidation activity respectively at 100 $\mu \mathrm{g} / \mathrm{mL}$ concentration (7).

As indicated in Table 5, the MNM and MSM extracts showed moderate activity $\left(\mathrm{IC}_{50}: 60.51\right.$ and $72.37 \mu \mathrm{g} / \mathrm{mL}$, respectively) in $\mathrm{DPPH}$ free radical scavenging activity. Other analyzed six extracts had weak or no activity in DPPH free radical scavenging activity test. Our results are in consistent with literature. Guder and Korkmaz published that the hydroalcoholic extracts of flower and leaf of $M$. neglecta demonstrated antioxidant activities with 59.00\% and $62.10 \%$ inhibition in DPPH free radical scavenging activity, respectively at $100 \mu \mathrm{g} / \mathrm{mL}$ concentration (7). In a literature survey, it is going to be found that there hasn't been any study about $M$. sherardiana.

As shown in Table 5, the MNM, MNW, MSM and MSW extracts showed $\mathrm{IC}_{50}: 45.81,55.02,41.20$ and $45.93 \mu \mathrm{g} /$ $\mathrm{mL}$ in ABTS cation radical scavenging assay, respectively. Particularly, the MSM extract indicate good activity in ABTS cation radical scavenging assay. The other tested four extracts had weak activity in ABTS cation radical scavenging assay. Cupric reducing effect was seen in none of the extracts. Because of that, data was not shown. In a literature survey, it is going to be found that there have not been any study about M. neglecta and M.sherardiana.

\section{Anticholinesterase Activity}

As shown in Table 5, all of the extracts of M. neglecta showed moderate activity against acetyl-and butyryl-cholinesterase enzymes, excluding MNW extract. Especially, the MNM extract was determined to have the highest activity in all tested extracts against acetyl-and butyryl-cholinesterase

Table 5. Total phenolic and flavonoid contents, antioxidant and anticholinesterase activities of M. neglecta and M. sherardiana extracts and galanthamine at $200 \mu \mathrm{g} / \mathrm{mL}^{\mathrm{x}}$

\begin{tabular}{|c|c|c|c|c|c|c|c|}
\hline Samples & $\begin{array}{l}\text { Inhibition \% } \\
\text { against AChE }\end{array}$ & $\begin{array}{l}\text { Inhibition \% } \\
\text { against BChE }\end{array}$ & $\begin{array}{l}\text { Phenolic content } \\
(\mu \mathrm{g} \text { PEs/mg extract })^{y}\end{array}$ & $\begin{array}{l}\text { Flavonoid content } \\
(\mu \mathrm{g} \text { QEs/mg extract })^{z}\end{array}$ & $\begin{array}{c}\text { Lipid } \\
\text { Peroxidation }\end{array}$ & $\begin{array}{c}\mathrm{IC}_{50}(\mu \mathrm{g} / \mathrm{mL}) \\
\text { DPPH Free Radical }\end{array}$ & ABTS Cation Radical \\
\hline MNP & $30.13 \pm 1.32^{\mathrm{a}}$ & $43.68 \pm 1.12^{\mathrm{a}}$ & - & - & $95.13 \pm 0.65^{\mathrm{a}}$ & $>200^{\mathrm{a}}$ & $127.03 \pm 1.03^{\mathrm{a}}$ \\
\hline MNA & $38.65 \pm 1.39^{\mathrm{b}}$ & $57.69 \pm 0.63^{b}$ & - & - & $45.92 \pm 0.29^{b}$ & $130.52 \pm 1.60^{\mathrm{b}}$ & $91.95 \pm 1.06^{\mathrm{b}}$ \\
\hline MNM & $53.68 \pm 0.42^{c}$ & $63.95 \pm 0.32^{c}$ & $68.29 \pm 0.14^{\mathrm{a}}$ & $15.58 \pm 0.19^{\mathrm{a}}$ & $23.42 \pm 0.48^{c}$ & $60.51 \pm 0.90^{c}$ & $45.81 \pm 0.82^{c}$ \\
\hline MNW & NA & $9.68 \pm 1.12^{\mathrm{d}}$ & - & - & $121.65 \pm 1.11^{\mathrm{f}}$ & $95.71 \pm 0.71^{\mathrm{c}}$ & $55.02 \pm 0.61^{\mathrm{g}}$ \\
\hline MSP & $\mathrm{NA}$ & $15.45 \pm 0.12^{\mathrm{e}}$ & - & - & $>200^{d}$ & $>200^{\mathrm{a}}$ & $106.93 \pm 0.23^{\mathrm{h}}$ \\
\hline MSA & $12.68 \pm 0.46^{\mathrm{a}}$ & $24.67 \pm 1 . .46^{\mathrm{f}}$ & - & - & $65.61 \pm 0.80^{\mathrm{g}}$ & $155.69 \pm 0.91^{\mathrm{b}}$ & $78.82 \pm 0.73^{\mathrm{i}}$ \\
\hline MSM & $21.68 \pm 0.57^{\mathrm{d}}$ & $17.09 \pm 0.33^{\mathrm{e}}$ & $86.59 \pm 0.27^{b}$ & $16.11 \pm 0.27^{\mathrm{a}}$ & $29.62 \pm 0.89^{\mathrm{h}}$ & $72.37 \pm 0.57^{\mathrm{e}}$ & $41.20 \pm 0.69^{j}$ \\
\hline MSW & $\mathrm{NA}$ & $07.07 \pm 0.33^{\mathrm{d}}$ & - & - & $135.82 \pm 1.91^{\mathrm{i}}$ & $104.60 \pm 1.26^{\mathrm{f}}$ & $45.93 \pm 0.12^{\mathrm{k}}$ \\
\hline Galanth. ${ }^{\mathrm{t}}$ & $84.59 \pm 0.41^{\mathrm{e}}$ & $82.39 \pm 0.59^{9}$ & - & - & - & - & - \\
\hline $\boldsymbol{a}-\mathrm{TOC}^{t}$ & - & - & - & - & $16.11 \pm 0.18^{j}$ & $17.51 \pm 0.33^{\mathrm{h}}$ & $9.08 \pm 0.08^{\mathrm{m}}$ \\
\hline BHT $^{\mathrm{t}}$ & - & - & - & - & $8.61 \pm 0.19^{k}$ & $49.68 \pm 0.19^{\mathrm{i}}$ & $10.59 \pm 0.19^{n}$ \\
\hline
\end{tabular}

${ }^{\mathrm{x}}$ Values expressed are means \pm S.D. of three parallel measurements $(p<0.05)$, ${ }^{\mathrm{Y} S t a n d a r d}$ drug, NA: Not active

${ }^{y}$ PEs, pyrocatechol equivalents $\left(\mathrm{y}=0.0164 \mathrm{x}+0.0266 \mathrm{R}^{2}=0.9969\right)$

${ }^{\mathrm{z}} \mathrm{QEs}$, quercetin equivalents ( $\mathrm{y}=0.1519 \mathrm{x}-0.1294 \mathrm{R}^{2}=0.9986$ )

t Standarts, the letters from ' $a$ ' to ' $n$ ' express the statistically diffences between the values. 
enzymes at $200 \mu \mathrm{g} / \mathrm{mL}$ (53.68 and 63.95\% inhibition, respectively). In despite of the $M$. neglacta, all extracts of $M$. sherardiana showed weak activity or no activity against acetyl-and butyryl-cholinesterase enzymes at $200 \mu \mathrm{g} / \mathrm{mL}$.

The current study has been the first study about Malva and Malvella genus anticholinesterase activty in literature. In this point of view, it is going to be an important data for this research area. In addition to that there are two studies about anticholinesterase activity of Malvaceae family that both of them relevant to Thespesia populnea. In this researches, it is reported that T. populnea bark is important for improving memory and determination of the potential of it in the management of Alzheimer patients would be beneficial (34).

\section{Determination of Antimicrobial Activity}

The antimicrobial activities of M. neglacta and M. sherardiana extracts against different microorganisms were assessed according to inhibition zone diameter. Results are presented in Table 6.
The petroleum ether and water extracts showed no activity at all against the five tested microorganisms (Data was not shown). The acetone and methanol extracts were active on all microorganisms tested with different zone diameters indicating weak (inhibition zone $<12$ ) and moderate antimicrobial activity (inhibition zone $<20-12$ ). The acetone extracts of $M$. neglacta and $M$. sherardiana showed moderate activity against $C$. albicans (inhibition zone 18 and $17 \mathrm{~mm}$, respectively). The acetone extract of $M$. sherardiana showed weak activity against E. coli, S. aureus, S. pyogenes and $P$. aeruginosa. The methanol extract was showed moderate activity against $C$. albicans, $P$. aeruginosa and weak activity against E. coli, S. aureus, S. pyogenes. The acetone and methanol extracts of $M$. neglacta showed moderate active on all microorganisms tested. The study of Mansouret al. showed that the ethanol extract of $M$. neglecta had activity on $S$. epidermidis, $S$. aureus and $P$. aeruginosa (6). The highest inhibitory zone was seen in ethanolic extract of $M$. neglecta against Staphylococcus epidermidis $(22 \mathrm{~mm})$.The present study is a first report for $M$. sherardiana.

Table 6. Zones of growth inhibition ( $\mathrm{mm}$ ) showing the antimicrobial activity of the M. neglectaand M. sherardiana extracts compared to that of positive controls

\begin{tabular}{|c|c|c|c|c|c|c|c|c|}
\hline & & & & & Microorga & & & \\
\hline & & & & E. coli & S. pyogenes & S. aureus & P. aeruginosa & C. albicans \\
\hline & & & $10 \mathrm{mg} / \mathrm{mL}$ & $12 \pm 0.3$ & $12 \pm 0.1$ & $11 \pm 0.3$ & $10 \pm 0.1$ & $16 \pm 0.2$ \\
\hline & & $\frac{0}{\tilde{e}}$ & $20 \mathrm{mg} / \mathrm{mL}$ & $14 \pm 0.2$ & $13 \pm 0.3$ & $12 \pm 0.2$ & $11 \pm 0.2$ & $16 \pm 0.3$ \\
\hline & ప艹ّ & & $30 \mathrm{mg} / \mathrm{mL}$ & $14 \pm 0.5$ & $12 \pm 0.4$ & $12 \pm 0.4$ & $13 \pm 0.4$ & $18 \pm 0.4$ \\
\hline ิ્⿷ & $\stackrel{5}{i}$ & & $10 \mathrm{mg} / \mathrm{mL}$ & $10 \pm 0.2$ & $11 \pm 0.1$ & $10 \pm 0.2$ & $12 \pm 0.1$ & $12 \pm 0.3$ \\
\hline$\Xi$ & & 馬 & $20 \mathrm{mg} / \mathrm{mL}$ & $11 \pm 0.1$ & $12 \pm 0.4$ & $10 \pm 0.2$ & $13 \pm 0.3$ & $12 \pm 0.4$ \\
\hline 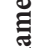 & & & $30 \mathrm{mg} / \mathrm{mL}$ & $13 \pm 0.2$ & $12 \pm 0.3$ & $13 \pm 0.3$ & $14 \pm 0.2$ & $14 \pm 0.1$ \\
\hline$\ddot{z}$ & & & $10 \mathrm{mg} / \mathrm{mL}$ & $9 \pm 0.1$ & $11 \pm 0.2$ & $10 \pm 0.2$ & $9 \pm 0.2$ & $15 \pm 0.2$ \\
\hline ฮี & $\Xi$ & 远 & $20 \mathrm{mg} / \mathrm{mL}$ & $12 \pm 0.5$ & $11 \pm 0.3$ & $10 \pm 0.3$ & $11 \pm 0.3$ & $16 \pm 0.3$ \\
\hline 总 & 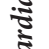 & & $30 \mathrm{mg} / \mathrm{mL}$ & $12 \pm 0.3$ & $11 \pm 0.2$ & $12 \pm 0.1$ & $11 \pm 0.4$ & $17 \pm 0.4$ \\
\hline & कั & $\overline{0}$ & $10 \mathrm{mg} / \mathrm{mL}$ & $10 \pm 0.3$ & $11 \pm 0.2$ & $9 \pm 0.3$ & $12 \pm 0.3$ & $11 \pm 0.1$ \\
\hline & $z$ & 氙 & $20 \mathrm{mg} / \mathrm{mL}$ & $11 \pm 0.2$ & $11 \pm 0.2$ & $9 \pm 0.1$ & $12 \pm 0.1$ & $12 \pm 0.1$ \\
\hline & & & $30 \mathrm{mg} / \mathrm{mL}$ & $11 \pm 0.4$ & $12 \pm 0.3$ & $10 \pm 0.2$ & $13 \pm 0.2$ & $14 \pm 0.3$ \\
\hline & & IPM $(10$ & & $19 \pm 1.4$ & $39.5 \pm 0.7$ & $27.5 \pm 0.7$ & $12 \pm 0$ & - \\
\hline & & Nystatin & & - & - & - & - & $25 \pm 0.5$ \\
\hline
\end{tabular}


Briefly, being used as food source and food supplement, M. neglacta and M. sherardiana are known as Tollk and Ebegümeci in Anatolia. Present study also showed that the $M$. neglacta and $M$. sherardiana methanol extracts have good activity in $\beta$-carotene bleaching, DPPH free radical scavenging and ABTS cation radical decolorisation assays. The antioxidant capacities of these extracts were parallel to the antioxidant properties of 4-hydroxy benzoic and salicylic acids which were the main components of these extracts.

Malva neglecta ve Malvella sherardiana'nın LC-MS / MS, GC / MS ile Kimyasal Profili ve Antikolinesteraz, Antimikrobiyal, Antioksidant Özellikleri ile Aflatoksin İçeriği

ÖZ

Bu çalışmanın amacı Malva neglecta ve Malvella sherardiana türlerinin antioksidan, antikolinesteraz ve antimikrobiyal aktiviterini, aflatoksin içeriği ile fenolik bileşik ve yağ asidi profillerini LC-MS/MS ve GC/MS ile belirlemektir. İncelenen yirmi yedi bileşikten, $M$. neglecta ve $M$. sherardiana türlerinde en bol bulunan bileşiklerin sırasıyla malik $(13108.97 \mu \mathrm{g} / \mathrm{g})$ ve $4-\mathrm{OH}$ benzoik asit $(2200.57 \mu \mathrm{g} / \mathrm{g})$ olduğu saptanmıştır. M. neglecta türünün metanol ekstresindeki toplam flavonoid içeriğin (15.58 $\mu g$ QEs/mg ekstre) toplam fenolik içerikten (68.29 $\mu \mathrm{g}$ PEs/
Thus, the species may help to protect the people against lipid peroxidation and free radical damage, and its extracts will probably be used for the development of safe food products and additives. The M. neglacta methanol extract also demonstrated good acetyl- and butyryl-cholinesterase inhibitory activities. Therefore, consumption of M. neglacta may be useful as good cholinesterase inhibitory agents. However, further studies, particularly in vivo tests, are needed to understand the activity in biological systems. mg ekstre) daha az olduğu belirlenmiştir. Bitkilerin metanol ekstresi çalışılan antioksidan aktivite belirleme yöntemlerinin tümünde en yüksek aktiviteyi göstermiştir. En iyi kolinesteraz enzim inhibisyonu ise $M$. neglecta türünün metanol ekstresi tarafından kaydedilmiştir (\%53.68 AChE enzim inhibisyonu ve \%63.95 BChE enzim inhibisyonu). Bitkilerin aseton ekstreleri ise $C$. albicans türüne karşı orta düzeyde antimikrobiyal aktivite göstermiştir. Bu çalışmadan elde edilen sonuçlar, $M$. neglecta ve $M$. sherardiana türlerinin yüksek fenolik asit içeriği ve antioksidan aktivitesinden dolayı besin kaynağı olarak kullanılabileceğini göstermektedir. Ayrıca ekstreler aflatoxin içermemektedir.

Anahtar kelimeler: Antikolinesteraz; antioxidan; Malva neglecta; Malvella sherardiana; LC-MS/MS, GC-MS

\section{REFERENCES}

1. Flora of Turkey and East Aegean Islands, Volume 2. Editor: Davis PH. Edinburgh University Press, Edinburgh. 1966, pp 179-242.

2. Akaydın G, Şimşek I, Arıtuluk ZC, Yeşilada E. An ethnobotanical survey in selected towns of the Mediterranean subregion (Turkey). Turk J Biol 2013;37: 230-47.

3. Yeşil Y, Akalın E. Folk medicinal plants in Kürecik Area (Akçadağ/Malatya-Turkey). Turk J Phar Sci 2009;2: 63-82.

4. Sezik E, Yaşilada E, Tabata M, Honda G, Takaishi Y, Fujita T. Traditional medicine in Turkey VIII. Folk medicine in East Anatolia, Erzurum, Erzincan, Area, Kars, Iğdır Provinces. Econ Bot 1997;51: 195-211.

5. Gurbuz I, Ozkan AM, Yesilada E, Kutsal O. Anti-ulcerogenic activity of some plants used in folk medicine of Pinarbasi (Kayseri, Turkey). J Ethnopharmacol 2005; 101: 313-8.

6. Mansouret SS, Koochak H, Darabpour E, Motamedi H. A survey on Hibiscus rosa-sinensis, Alcea rosea L. and Malva neglecta Wallr as antibacterial agents. Asian Pac J Trop Med 2010;3: 351-2.

7. Guder A, Korkmaz H. Evaluation of in-vitro antioxidant properties of hydroalcoholic solution extracts Urtica dioica L., Malva neglecta Wallr. and their mixture. Iran J Pharm Res 2012;1: 913-23.

8. Dalar A, Türker M, Konczak I. Antioxidant capacity and phenolic constituents of Malva neglecta Wallr. and Plantago lanceolata L. from Eastern Anatolia Region of Turkey. J Herb Med 2012;2: 42-51.

9. Ghanati F, Khatami F. Polyphenols and their antioxidant activity in callus-cultured Malva Neglecta cells under UV-B and UV-C irradiation. Planta Med 2011;77: 1286-9.

10. Turker M, Dalar A. In vitro antioxidant and enzyme inhibitory properties and phenolic composition of $M$. neglecta Wallr. (Malvaceae) fruit: A traditional medicinal fruit from Eastern Anatolia. Ind Crop Prod 2013; 51: 376-80.

11. Barros L, Duenas M, Carvalho AM, Ferreira ICFR, SantosBuelga C. Characterization of phenolic compounds in flowers of wild medicinal plants from Northeastern Portugal. Food Chem Toxicol 2012;50: 1576-82.

12. Daniela A, Pichichero E, Canuti L, Cicconi R, Karou D, D’arcangelo G, A Canini. Identification of phenolic compounds from medicinal and melliferous plants and their cytotoxic activity in cancer cells. Caryologia 2007;60: 90-5.

13. Khidyrova NK and Shakhidoyatov KHM. Plant polyprenols and their biological activity. Chem Nat Compd (Khim Prir Soedin) 2002;38: 107-21.

14. Ertaş A, Boğa M, Haşimi N, Yeşil Y, Gören AC, Topcu G, Kolak U. Antioxidant, anticholinesterase, antimicrobial activities and fatty acid constituents of Achillea cappadocica Hausskn. et Bornm. Turk J Chem 2014;38: 592-9.

15. Altun M, Gören AC. Essential Oil Composition of Satureja cuneifolia by simultaneous distillation-extraction and thermal 
desorption GC-MS techniques. J Essent Oil Bear Pl 2007;10: 139-44.

16. Ertaş A, Boğa M, Haşimi N, Yılmaz MA. Fatty acid and essential oil compositions of Trifolium angustifolium var. angustifolium with antioxidant, anticholinesterase and antimicrobial activities Iran J Pharm Res 2015;14: 233-4.

17. Slinkard K, Singleton VL. Total phenol analyses: Automation and comparison with manual methods. Am J Enol Viticult 1977;28: 49-55.

18. Moreno MIN, Isla MI, Sampietro AR, Vattuone MA. Comparison of the free radical scavenging activity of propolis from several regions of Argentina. J Ethnopharmacol 2000;71: 109-14.

19. Miller HE. A simplified method for the evaluation of antioxidants. J Am Oil Chem Soc 1971;48: 91-105.

20. Apak R, Guclu K, Ozyurek M, Karademir SE. Novel total antioxidant capacity index for dietary polyphenols and vitamins $\mathrm{C}$ and $\mathrm{E}$, using their cupric ion reducing capability in the presence of neocuproine: CUPRAC Method. J Agr Food Chem 2004;52: 7970-81.

21. Oran S, Sahin S, Sahinturk P, Ozturk S, Demir C. Antioxidant and antimicrobial potential and HPLC analysis of stictic and usnic acids of three Usnea species from Uludag Mountain (Bursa, Turkey) Iran J Pharm Res 2016;15: 527-35.

22. Delnavazi M, Hadjiakhoondi A, Delazar A, Ajani Y, S Tavakoli, Yassa N. Phytochemical and antioxidant investigation of the aerial parts of Dorema glabrum Fisch. \& C. A. Mey Iran J Pharm Res 2015;14: 925-31.

23. Nickavar B, Rezaee J, Nickavar A. Effect-directed analysis for the antioxidant compound in Salvia verticillata. Iran J Pharm Res 2016;15: 241-246.

24. Ellman GL, Courtney KD, Andres V, Featherstone RM. A new and rapid colorimetric determination of acetylcholinesterase activity, Biochem Pharmacol 1961;7: 88-95.

25. Boğa M, Ertaş A, Yılmaz MA, Kızıl M, Çeken B, Haşimi N, Yllmaz Özden T, Demirci S, Yener İ, Deveci Ö.
UHPLC-ESI-MS/MS and GC-MS analyses on phenolic, fatty acid and essential oil of Verbascum pinetorum with antioxidant, anticholinesterase, antimicrobial and DNA damage protection effects. Iran J Pharm Res 2016;15: 393-405.

26. NCCLS (National Committee for Clinical Laboratory Standards). Performance Standards for Antimicrobial Disk Susceptibility Test. 6th ed. Approved Standard M2-A6 Wayne Pa. 1997.

27. Ertaş A, Boğa M, Yılmaz MA, Yeşil Y, Haşimi N, Kaya MS, Temel H, Kolak U. Chemical compositions by using LC-MS/ MS and GC-MS and biological activities of Sedum sediforme (Jacq.) Pau. J Agr Food Chem 2014;62: 4601-9.

28. Ertaş A, Yilmaz MA, Firat M. Chemical profile by LC-MS/ MS, GC/MS and antioxidant activities of the essential oils and crude extracts of two Euphorbia species. Nat Prod Res 2015;29: 529-34.

29. Mousavi SNM, Delazar A, Nazemiyeh H, Khodaie I. Biological activity and phytochemical study of Scutellaria platystegia. Iran J Pharm Res 2015;14: 215-23.

30. Fahimi S, Mortazavi SA, Abdollahi M, Hajimehdipoor H. Formulation of a traditionally used polyherbal product for burn healing and HPTLC fingerprinting of its phenolic contents. Iran J Pharm Res 2016;15: 95-105.

31. Dowd MK. Identification of the unsaturated heptadecyl fatty acids in the seed oils of Thespesia populnea and Gossypium hirsutum J Am Oil Chem Soc 2012;89: 1599-1609.

32. Tesevic V, Vajs V, Lekic S, Dordevic I, Novakovic M, Vujisic L, Todosijevic M. Lipid composition and antioxidant activities of the seed oil from three Malvaceae species. Arch Biol Sci 2012;64: 221-7.

33. Kiliç CS, Aslan S, Kartal M, Coskun M. Fatty Acid Composition of Hibiscus trionum L. (Malvaceae). Rec Nat Prod 2011;5: 659.

34. Vasudevan M, Parle M. Pharmacological actions of Thespesia populnea relevant to Alzheimer's disease. Phytomedicine 2006;13: 677-87. 